\title{
Nathaniel Southgate Shalek
}

\section{Richard Elwood Dodge}

To cite this article: Richard Elwood Dodge (1906) Nathaniel Southgate Shalek, Journal of Geography, 5:7, 326-327, DOI: 10.1080/00221340608986138

To link to this article: http://dx.doi.org/10.1080/00221340608986138

\section{曲 Published online: 20 May 2008.}

Submit your article to this journal 전

Џll Article views: 3

Q View related articles $\sqsubset$ 


\section{EDITORIAL}

\section{NATHANIEL SOUTHGATE SHALER}

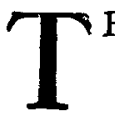

HE death of Professor Nathaniel Southgate Shaler, on April Io last, has brought vividly to the minds of many of the geography teachers of the country and to hosts of others the question as: to what makes a man or woman a great teacher. The more than five thousand students who had voluntarily come under his influence in his classes, are by their very number a witness to the fact that Professor Shaler was, unlike many teachers, not a mere imparter of information, a hearer of lessons, or a lecturer who slowly and begrudgingly traversed the well worn path of previous years. These students were led to his classes by the tradition that had existed for several college generations that everyone ought to take at least one course with Professor Shaler, "not so much for the subject as for the man." This tradition was founded on the knowledge which gradually grew stronger as the successive classes came and went, that here was a man who taught because he loved to teach, and hence taught well; who was filled with interest in young men, and hence fitted his subject to his hearers and not his hearers to his subject; who had a keen knowledge of human nature that enabled him quickly to fathom the thoughts and feelings of his young friends, and hence to gain their confidence as well as their esteem.

The students who sat under Professor Shaler felt, as they had every right to feel, that their teacher was their friend, who would gladly discuss with them the affairs of their life and give them advice and help from the fullness of his experience at any time. They listened to him as he told them the story of the earth and made it personal, until as the weeks went on they found that they were gaining an insight into the world about them which was not merely something new, but different from anything that could be gained from books or from reading. Many were led, because of their teacher's inspiring leadership, to look further and deeper into the subject and to follow the science of geology as a profession just because their first introduction to the science was made so mind-opening. The large majority went forth from his classes broader in their mental vision, more in sympathy with nature, more keen to analyze the problems of science presented to them daily, and with a deep conviction that they had gained a mental altitude that gave them a broader and more human outlook on the world. These thousands felt, as they heard the sad news of Professor Shaler's death, that they had lost a near personal friend, and that one of 
the strongest personalities associated with their memories of their Alma Mater had passed away, and that the college would ever be different to them in subsequent visits.

Those who had come more closely in contact with Professor Shaler, who had been with him day after day for several years, felt that the world had suddenly stopped for a brief moment and that their lives would be different ever afterwards. They could not believe the sad news; and, as they looked back over their many years of friendship and association and analyzed the question as to what it was that made Professor Shaler so dear to them, saw that the growth of their esteem had been through several stages. As youths they were inspired by his wonderful exposition in the class-room, and by his deep love for all that was noble and pure; as the years went on they came to love him because of his breadth of sympathy, his versatility and his nobleness, which could not be appreciated in early acquaintance because their knowledge was not deep enough. Those who knew him longest loved him because of all these qualities and many others that became deeper and richer as the years advanced. Above all and through all shone the deep humanity of the man, evidenced in his every thought, suggestion and act. It was this deep human interest in and sympathy with all phases of life and endeavor that made him a man so far different from his fellowmen and beloved by all who knew him-and many who did not. He was a splendid example of the fact that great teachers are, above all, great men and women, and that the personality of a teacher is a more vital asset than his learning or his training in the ways of teacher. Professor Shaler was a great teacher because he was primarily a broad-minded, big-hearted man, vigorous of speech, keen of mind, quick of action, versatile beyond belief almost, always interested in everything about him however remote or seemingly trivial. He sacrificed his strength in every way in the service of his fellows; but his influence will go on through the generations, by his books and writings, but more especially by the teachings of those he taught to teach, by example. Professor Shaler was very fond of quoting, with deep reverence and feeling, "My master, Louis Agassiz." He leaves behind a vast number of students who feel equally keenly that Professor Shaler was their master and who will reverence his memory as they will never forget his example or lose the influence of his inspiration.

Richard Elwood Dodge. 